\title{
Chemical components of volatile oil from Cinnamomum jensenianum Hand Mazz leaf in Yongzhou, and its antibacterial and antioxidant properties
}

\author{
Shao Jinhua ${ }^{1,2}$, Zhang Yufei ${ }^{3}$, Zhu Zhiyong ${ }^{1,2}$, Chen Xiaoming ${ }^{1,2}$, He Fulin ${ }^{1,2 \star}$ \\ ${ }^{1}$ Hunan Key Laboratory of Plant Resources Utilization. Hunan University of Science and Engineering, ${ }^{2}$ Hunan Provincial \\ Engineering Research Center for Ginkgo Biloba, Yongzhou, ${ }^{3}$ Mudanjiang Medical University, Mudanjiang, Heilongjiang 157011 , \\ China
}

*For correspondence: Email: ra1216@163.com

Sent for review: 11 June 2018

Revised accepted: 26 August 2018

\begin{abstract}
Purpose: To study the chemical components, and in vitro antibacterial and antioxidant properties of volatile oil extracted from Yongzhou Cinnamomum jensenianum Hand. Mazz leaves.

Methods: The extraction process of volatile oil in the leaves of Yongzhou Cinnamomum jensenianum Hand. Mazz was optimized with respect to volatile oil yield, and the oil was subjected to gas chromatography-mass spectrometry (GC-MS) analysis. In vitro antimicrobial activities against bacteria and fungi were evaluated by the filter paper method, while in vitro antioxidant potential was determined by assaying its ability to scavenge DPPH radicals.

Results: The optimized extraction conditions for volatile oil from the leaves of Yongzhou Cinnamomum jensenianum Hand. Mazz were $3.5 \mathrm{~h}$ extraction time, solid-liquid ratio of 1:10, and soaking time of $4 \mathrm{~h}$, which resulted in volatile oil yield of $2.4 \pm 0.19 \%$. A total of 37 components were isolated and identified, accounting for $99.19 \%$ of the volatile oil. The in vitro antimicrobial activities against bacteria and fungi were significant, with minimum inhibitory concentration (MIC) between 10 and $20 \mathrm{uL}$. At a volatile oil concentration of $0.09 \mathrm{mg} / \mathrm{mL}$, the DPPH scavenging ability of the oil was stronger than that of BHT.

Conclusion: There is a high level of extractability of volatile oil from the leaves of Yongzhou Cinnamomum jensenianum Hand. Mazz. The main component is linalool (94.45\%), and it has good antibacterial and antioxidant properties.
\end{abstract}

Keywords: Yongzhou Cinnamomum jensenianum Hand. Mazz, Volatile oil, Antibacterial, Antioxidant

\begin{abstract}
This is an Open Access article that uses a funding model which does not charge readers or their institutions for access and distributed under the terms of the Creative Commons Attribution License (http://creativecommons.org/licenses/by/4.0) and the Budapest Open Access Initiative (http://www.budapestopenaccessinitiative.org/read), which permit unrestricted use, distribution, and reproduction in any medium, provided the original work is properly credited.
\end{abstract}

Tropical Journal of Pharmaceutical Research is indexed by Science Citation Index (SciSearch), Scopus, International Pharmaceutical Abstract, Chemical Abstracts, Embase, Index Copernicus, EBSCO, African Index Medicus, JournalSeek, Journal Citation Reports/Science Edition, Directory of Open Access Journals (DOAJ), African Journal Online, Bioline International, Open-J-Gate and Pharmacy Abstracts

\section{INTRODUCTION}

Cinnamomum jensenianum Hand. Mazz is a member of the genus Polygonaceae and is distributed in Hubei, Hunan, Guizhou, Sichuan and Jiangxi Province [1-3]. Its branches and fruits contain aromatic oils that can be used as industrial raw materials. At present, only few studies have been carried out on the chemical components of Cinnamomum jensenianum Hand. Mazz, and there are only two studies on the analysis of the volatile components of the leaves of Yongzhou Cinnamomum jensenianum Hand. Mazz and their antimicrobial activities. 
There are significant differences in the anatomical characteristics, tissue structure, and material content of Cinnamomum jensenianum grown in different regions [4-6]. Therefore, it is necessary to study the extraction process and the in vitro biological activities of Yongzhou Cinnamomum jensenianum Hand. Mazz [7-9].

In this study, volatile oil was extracted from Cinnamomum jensenianum by stream distillation, and analyzed by GC-MS. The results were compared with previous data through database search for qualitative and quantitative analyses. The oil was also assessed for antioxidant property using $\mathrm{DPPH}^{*}$ scavenging assay, in addition to determination of its in vitro antibacterial activity.

\section{EXPERIMENTAL}

Yongzhou Cinnamomum jensenianum Hand. Mazz was purchased from Hunan Health-Guard Bio-tech Inc. (product number = 151109). The product was shade-dried to a constant weight, and then ground, sifted, sealed in a plastic bag, and stored in the refrigerator at $4{ }^{\circ} \mathrm{C}$

\section{Reagents}

Sodium sulfate $\left(\mathrm{Na}_{2} \mathrm{SO}_{4}\right)$ was purchased from Sinopharm Chemical Reagent Co., Ltd (Shanghai, China); ethyl ether was purchased from Shenzhen Jianyuan Chemical Co., Ltd. (Shenzhen, China); Bacillus subtilis ATCC6633, Staphylococcus aureus ATCC06538 and Escherichia coli CMCC44103 were provided by Chengdu Institute of Biology, Chinese Academy of Sciences, Culture Collection Center. Penicillium notatum and Aspergillus niger were provided by the microbiology laboratory of Hunan University of Science and Engineering.

\section{Extraction of volatile oil}

The plant product $(100 \mathrm{~g})$ was soaked in distilled water in a 2,000-mL round-bottomed flask for a period of time, and extracted with a volatile oil extractor. The oily liquid in the volatile oil extractor was dehydrated over anhydrous $\mathrm{Na}_{2} \mathrm{SO}_{4}$.

\section{Estimation of volatile oil yield}

The yield of volatile oil was calculated according to Eq 1.

$$
C=\left\{\left(m_{1}-m_{2}\right) / m_{3}\right\}
$$

where $\mathrm{C}$ (in \%) is the yield of volatile oil; $\mathrm{m}_{1}$ (in $\mathrm{g}$ ) is weight of the bottle and oil; $m_{2}$ (in $g$ ) is the weight of bottle; $\mathrm{m}_{3}$ (in $\mathrm{g}$ ) is the weight of dried powder of product.

\section{Optimization of extraction conditions of volatile oil}

\section{Influence of duration of extraction on volatile oil yield}

Five (5) parts (100 g each) of dry powder were placed separately in $2000-\mathrm{mL}$ round bottom flasks, and $1200 \mathrm{~mL}$ of distilled water was added. The mixture was allowed to soak for $8 \mathrm{~h}$, and then extracted with a volatile oil extractor for different periods i.e. 2, 3, 4, 5, and $6 \mathrm{~h}$. In each case, the oily liquid in the volatile oil extractor was collected and dried over anhydrous sodium sulfate. The yield of volatile oil was calculated to determine the optimum extraction time.

\section{Influence of powder: liquid ratio on yield of volatile oil}

Five (5) parts (100 g each) of dry powder were put separately in $2000-\mathrm{mL}$ round bottom flasks, and $600,800,1000,1200$, and $1400 \mathrm{~mL}$ of distilled water were added to different flasks. The mixtures were allowed to soak for $8 \mathrm{~h}$, and then extracted with a volatile oil extractor for $4 \mathrm{~h}$.

The oily liquid in the volatile oil extractor was collected and dried over anhydrous sodium sulfate. The yield of volatile oil was calculated to determine the optimum solid-liquid ratio.

\section{Impact of soaking duration on volatile oil yield}

Five parts (100 g each) of dry powder were mixed separately with $1200-\mathrm{mL}$ portions of distilled in 2000-mL round bottom flasks for different periods of time, ranging from 2 to $10 \mathrm{~h}$. They were then extracted with a volatile oil extractor for $4 \mathrm{~h}$.

The oily liquid in the volatile oil extractor was collected and dried as usual over anhydrous sodium sulfate, and the oil yield was calculated to determine the optimum soaking time.

\section{Orthogonal experiment}

In order to determine the optimum extraction conditions for the volatile oil, the extraction time (A), liquid-solid ratio (B) and soaking time (C) were evaluated, and L9 $\left(3^{3}\right)$ was used for orthogonal studies on the basis of outcomes of the single factor extraction studies above. The design is shown in Table 1. 
Table 1: Design used for orthogonal test

\begin{tabular}{cccc}
\hline No. & $\mathbf{A}(\mathbf{h})$ & $\mathbf{B}(\mathbf{g} / \mathbf{m L})$ & $\mathbf{C}(\mathbf{h})$ \\
\hline 1 & 3 & $10: 1$ & 6 \\
2 & 4 & $12: 1$ & 8 \\
3 & 5 & $14: 1$ & 10 \\
\hline
\end{tabular}

\section{Conditions for GC-MS analysis}

The volatile oil was subjected to GC-MS analysis in a Perkin Elmer TurboMass GC mass spectrometer at a temperature of $270{ }^{\circ} \mathrm{C}$ and 5min desorption. An Agilent HP-1 column of dimensions $30 \mathrm{~m} \times 0.25 \mathrm{~mm}$, and stationary phase thickness of $0.25 \mu \mathrm{m}$ ( $\mathrm{J} \& \mathrm{~W}$ Scientific) was used, with helium as carrier gas at the rate of $1 \mathrm{~mL} / \mathrm{min}$. The injection volume and split ratio were $1 \mu \mathrm{L}$ and 20:1, respectively, and the precolumn pressure was $8.04 \mathrm{psi}(55.44 \mathrm{k} \mathrm{Pa})$. The column temperature was maintained for $3 \mathrm{~min}$ at $60{ }^{\circ} \mathrm{C}$, raised at $10{ }^{\circ} \mathrm{C}$ per min to $280{ }^{\circ} \mathrm{C}$, and kept constant for $10 \mathrm{~min}$ at $280{ }^{\circ} \mathrm{C}$. The mass detector used functioned at $70 \mathrm{eV}$ within $30-$ $600 \mathrm{~m} / \mathrm{z}$ in ionization mode, with an interface temperature of $230{ }^{\circ} \mathrm{C}$. The MS database was NIST05a. 5L.

\section{Determination of antibacterial activity of volatile oil}

Disc diffusion procedure was used to determine the diameter of the zone of inhibition of the volatile oil. The minimum inhibitory concentration (MIC) was estimated as outlined previously [10].

\section{Evaluation of DPPH radical scavenging capacity of volatile oil}

Equal volumes of $0.03,0.06,0.09,0.12,0.15$, and $0.18 \mathrm{mg} / \mathrm{mL}$ Cinnamomum jensenianum Hand. Mazz volatile oil in different test tubes were incubated with $2 \mathrm{~mL}$ of $0.1 \mathrm{mmol} / \mathrm{L} \mathrm{DPPH}$ solution for $30 \mathrm{~min}$ in the dark. The absorbance $\left(A_{i}\right)$ of each tube was measured at $518 \mathrm{~nm}$ [11]. A mixture of equal volumes of ethanol solution of volatile oil, and anhydrous ethanol was similarly treated, but without DPPH $\cdot$, and the absorbance $\left(A_{j}\right)$ was measured at $518 \mathrm{~nm}$. In another tube, equal volumes of ethanol and DPPH - solution were also treated similarly, and the absorbance $\left(A_{0}\right)$ was determined. $A$ tube containing $B H T$ in place of volatile oil served as control, and the $\mathrm{DPPH} \cdot$ scavenging capacity (W) was estimated using the equation 2 .

$W=\left\{1-\left[\left(A_{i}-A_{j}\right) / A_{0}\right]\right\} \times 100$

where $\mathrm{W}$ (in \%) is the DPPH radical scavenging capacity; $A_{i}$ is the absorbance of volatile oil solution and DPPH; $A_{j}$ is the absorbance of oil solution and anhydrous ethanol; and $A_{0}$ is the absorbance of the control.

\section{Statistical analysis}

The results are presented as mean \pm standard deviation (SD). They were analyzed for statistically significant differences using Duncan multiple comparison (SSR method). All analyses were done with Microsoft Office 2007, Design Expert 8. $0.5 \mathrm{~b}$ and SPSS. Values of $p<0.05$ were taken as indicative of significant differences between treatments groups.

\section{RESULTS}

\section{Single-factor optimization}

\section{Influence of duration of soaking on volatile oil yield}

Figure 1 shows the effect of soaking time on the yield of volatile oil. The yield of volatile oil increased with increase in the duration of soaking, and attained a maximum value at a soaking time of $8 \mathrm{~h}$. Beyond $8 \mathrm{~h}$, the yield of volatile oil was almost constant.

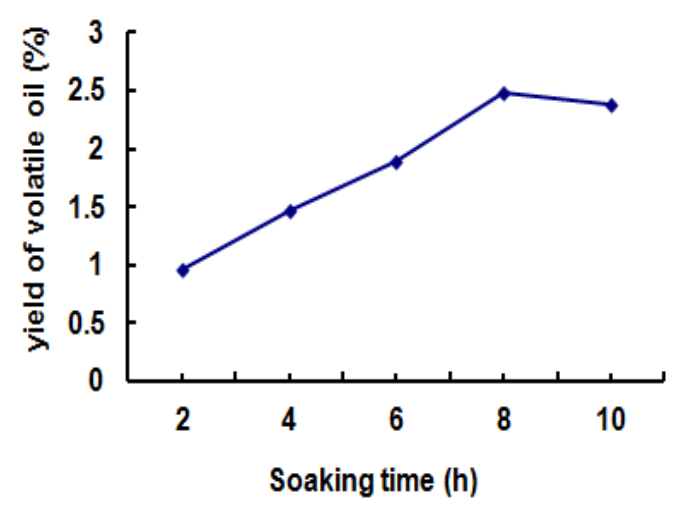

Figure 1: Effect of soaking time on the yield of volatile oil. Different letters indicate significant differences between groups

\section{Effect of extraction time on the yield of volatile oil}

The yield of volatile oil increased as extraction time was increased, and reached maximum when the duration of extraction was $4 \mathrm{~h}$ (Figure 2). However, the yield stabilized beyond $4 \mathrm{~h}$ and became almost constant, indicating that the volatile oil was already completely extracted.

\section{Effect of powder:liquid ratio on the yield of volatile oil}

The effect of powder : liquid ratio on the yield of volatile oil is shown in Figure 3. The yield of 
volatile oil increased with increase in the amount of distilled water used. The yield of volatile oil reached maximum at powder : liquid ratio of $1: 12$. However, with further increase in distilled water, the yield of volatile oil showed a downward trend.

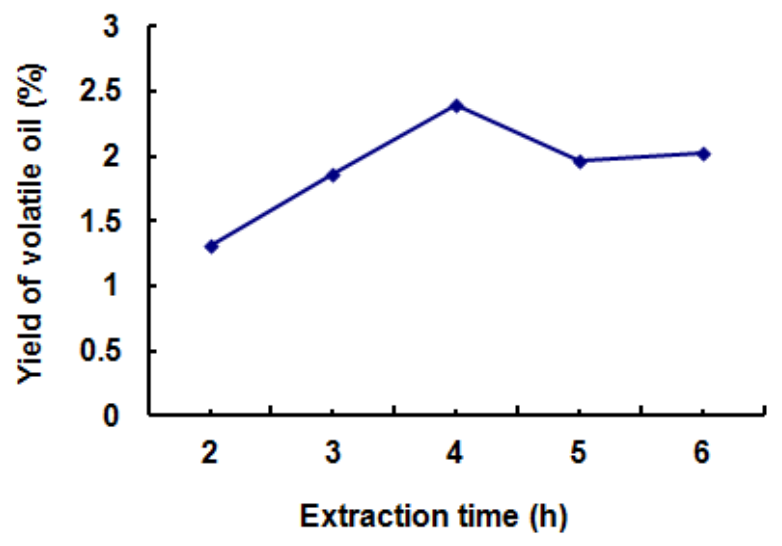

Figure 2: Effect of extraction time on the yield of volatile oil. Different letters indicate significant differences between groups

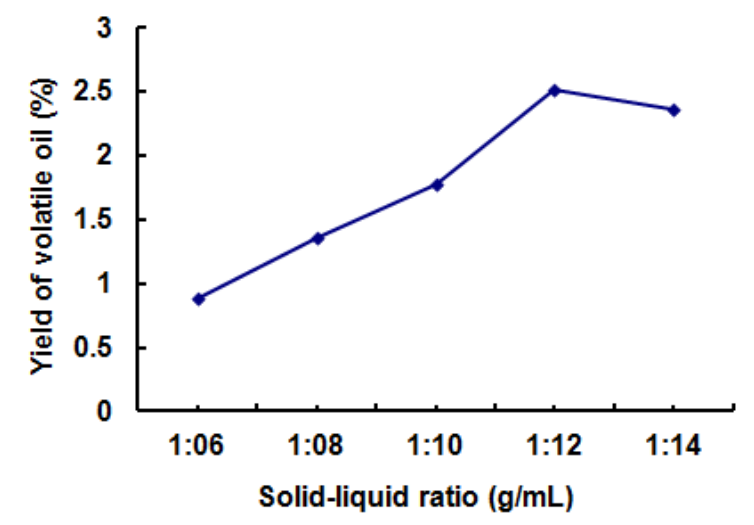

Figure 3: Influence of solid (powder): liquid ratio on oil yield. Different letters indicate significant differences between groups

Table 2: Outcome of orthogonal experiment

\section{Orthogonal optimization}

From Table 2, the order of factors that affect the yield of volatile oils was: $A>B>C$, and the optimum process parameters were $A_{3} B_{2} C_{3}$, i.e. extraction time of $5 \mathrm{~h}$, solid-liquid ratio of $1: 12$, and soaking duration of $10 \mathrm{~h}$.

\section{GC-MS results}

Thirty-seven compounds were isolated and identified, accounting for $99.19 \%$ of the volatile oil. The main chemical component was linalool (1,6-octadien-3-ol) which accounted for 94.45 $\%)$. The other components were present in trace amounts (Table 3).

\section{Antibacterial activity}

As shown in Table 4, the volatile oil exerted the strongest antibacterial ability against Aspergillus niger while the effect on Penicillium, $B$. subtilis, $S$. aureus, and $E$. coli was milder. The antibacterial activity against fungi was stronger than that against bacteria.

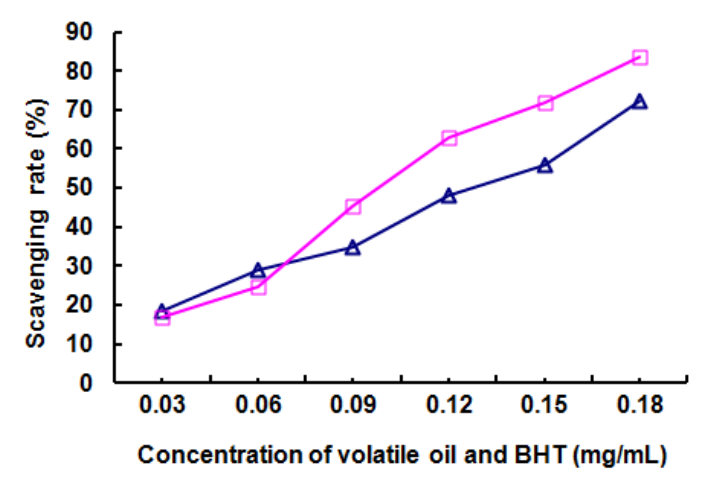

Figure 4: DPPH • scavenging capacity of volatile oil, relative to that of $\mathrm{BHT}$. Different letters indicate significant differences between the two. $\square=$ Scavenging by volatile oil; $\Delta=$ Scavenging by BHT

\begin{tabular}{crccc}
\hline Test number & $\mathbf{A}(\mathbf{h})$ & $\mathbf{B}(\mathbf{m L} / \mathbf{g})$ & $\mathbf{C}(\mathbf{h})$ & Yield of volatile oil (\%) \\
\hline 1 & 1 & 1 & 1 & 0.6 \\
2 & 1 & 2 & 2 & 1.6 \\
3 & 1 & 3 & 3 & 1.5 \\
4 & 2 & 1 & 2 & 1.8 \\
5 & 2 & 2 & 3 & 2.3 \\
6 & 2 & 3 & 1 & 2.0 \\
7 & 3 & 1 & 3 & 2.1 \\
8 & 3 & 2 & 1 & 2.0 \\
9 & 3 & 3 & 2 & 2.2 \\
$k_{1}$ & 1.233 & 1.500 & 1.533 & \\
$k_{2}$ & 2.033 & 1.967 & 1.867 & \\
$k_{3}$ & 2.100 & 1.900 & 1.967 & \\
$R$ & 0.867 & 0.467 & 0.434 & \\
\hline
\end{tabular}


Table 3: Chemical components of volatile oil from Yongzhou Cinnamomum jensenianum

\begin{tabular}{|c|c|c|c|c|c|}
\hline S/no. & $\begin{array}{l}\text { Retention } \\
\text { time/min }\end{array}$ & Chemical components & $\begin{array}{l}\text { Molecular } \\
\text { Formula }\end{array}$ & $\begin{array}{l}\text { Molecular } \\
\text { weight }\end{array}$ & $\begin{array}{l}\text { Relative } \\
\text { Content (\%) }\end{array}$ \\
\hline 1 & 5.395 & Alpha-pinene & $\mathrm{C}_{10} \mathrm{H}_{16}$ & 136.2 & 0.071 \\
\hline 2 & 6.694 & Alpha-phellandrene & $\mathrm{C}_{10} \mathrm{H}_{16}$ & 136.3 & 0.02 \\
\hline 3 & 7.062 & 1-Methyl-4-(1-methylethyl) benzene & $\mathrm{C}_{10} \mathrm{H}_{14}$ & 134.1 & 0.059 \\
\hline 4 & 7.135 & D-Limonene & $\mathrm{C}_{10} \mathrm{H}_{16}$ & 136.2 & 0.056 \\
\hline 5 & 7.467 & 4-Hydroxybenzaldehyde & $\mathrm{C}_{7} \mathrm{H}_{6} \mathrm{O}_{2}$ & 122.03 & 0.054 \\
\hline 6 & 7.933 & $\begin{array}{l}\text { Alpha-methyl-alpha-[4-methyl-3- } \\
\text { pentenyl]oxiranemethanol }\end{array}$ & $\mathrm{C}_{10} \mathrm{H}_{18} \mathrm{O}_{2}$ & 170.13 & 0.628 \\
\hline 7 & 8.216 & $\begin{array}{l}\text { 2-Furanmethanol,5-ethenyltetrahydro-alpha, } \\
\text { alpha,5-trimethyl-, cis- }\end{array}$ & $\mathrm{C}_{10} \mathrm{H}_{18} \mathrm{O}_{2}$ & 170.13 & 0.772 \\
\hline 8 & 8.537 & 1,6-Octadien-3-ol & $\mathrm{C}_{10} \mathrm{H}_{18} \mathrm{O}$ & 154.13 & 94.449 \\
\hline 9 & 9.612 & $\begin{array}{l}2 \mathrm{H} \text {-Pyran-3-ol,6-ethenyltetrahydro-2,2,6- } \\
\text { trimethyl- }\end{array}$ & $\mathrm{C}_{10} \mathrm{H}_{18} \mathrm{O}_{2}$ & 170.13 & 0.059 \\
\hline 10 & 10.005 & Estragole & $\mathrm{C}_{10} \mathrm{H}_{12} \mathrm{O}$ & 148.08 & 0.055 \\
\hline 11 & 10.802 & $\begin{array}{l}\text { 1,6-Octadien-3-ol,3,7-dimethyl-,3-(2- } \\
\text { aminobenzoate) }\end{array}$ & $\mathrm{C}_{17} \mathrm{H}_{23} \mathrm{NO}_{2}$ & 273.17 & 0.052 \\
\hline 12 & 11.062 & 2,6-Octadienal, 3,7-dimethyl- & $\mathrm{C}_{10} \mathrm{H}_{16} \mathrm{O}$ & 152.12 & 0.025 \\
\hline 13 & 11.147 & Cinnamaldehyde, (E)- & $\mathrm{C}_{9} \mathrm{H}_{8} \mathrm{O}$ & 132.05 & 0.069 \\
\hline 14 & 11.304 & $\begin{array}{l}\text { 1,7,7-TRIMETHYLBICYCLO } \\
\text { [2.2.1] HEPT-2-YL PHENYLACETATE }\end{array}$ & $\mathrm{C}_{12} \mathrm{H}_{4} \mathrm{O}_{3}$ & 196.14 & 0.183 \\
\hline 15 & 12.325 & Eugenol & $\mathrm{C}_{10} \mathrm{H}_{12} \mathrm{O}_{2}$ & 164.08 & 0.029 \\
\hline 16 & 13.195 & $\begin{array}{l}\text { (1R,4Z,9S)-4,11,11-trimethyl-8- } \\
\text { methylidenebicyclo[7.2.0]undec-4-ene }\end{array}$ & $\mathrm{C}_{15} \mathrm{H}_{24}$ & 204.18 & 0.289 \\
\hline 17 & 13.491 & Benzofuran & $\mathrm{C}_{8} \mathrm{H}_{6} \mathrm{O}$ & 118.04 & 0.12 \\
\hline 18 & 13.636 & alpha-Caryophyllene & $\mathrm{C}_{15} \mathrm{H}_{24}$ & 204.18 & 0.256 \\
\hline 19 & 14.464 & $\begin{array}{l}\text { Naphthalene, } 1,2,3,5,6,8 a-h e x a h y d r o-4,7- \\
\text { dimethyl-1-(1-methylethyl)- }\end{array}$ & $\mathrm{C}_{15} \mathrm{H}_{24}$ & 204.18 & 0.271 \\
\hline 20 & 14.736 & alpha-Calacorene & $\mathrm{C}_{15} \mathrm{H}_{20}$ & 200.15 & 0.024 \\
\hline 21 & 14.881 & 1,6,10-Dodecatrien-3-ol, 3,7,11-trimethyl- & $\mathrm{C}_{15} \mathrm{H}_{26} \mathrm{O}$ & 222.19 & 0.526 \\
\hline 22 & 15.183 & $\begin{array}{l}1 \mathrm{H} \text {-Cycloprop[e]azulen-7-ol,decahydro-1,1,7- } \\
\text { trimethyl-4-methylene-, }\end{array}$ & $\mathrm{C}_{15} \mathrm{H}_{24} \mathrm{O}$ & 220.18 & 0.261 \\
\hline 23 & 15.267 & Caryophyllene oxide & $\mathrm{C}_{15} \mathrm{H}_{24} \mathrm{O}$ & 220.18 & 0.638 \\
\hline 24 & 15.376 & Guaiol & $\mathrm{C}_{15} \mathrm{H}_{26} \mathrm{O}$ & 222.19 & 0.077 \\
\hline 25 & 15.57 & 3-Cyclohexen-1-carboxaldehyde & $\mathrm{C}_{9} \mathrm{H}_{14} \mathrm{O}$ & 138.10 & 0.11 \\
\hline 26 & 15.878 & $\begin{array}{l}\text { 1-Methyl-4-((E)-1,5,9-trimethyl-8-methylene- } \\
\text { dec-4-enyl)-2,3-dioxa-bicyclo[2.2.2]oct-5- } \\
\text { ene }\end{array}$ & $\mathrm{C}_{15} \mathrm{H}_{24}$ & 204.18 & 0.156 \\
\hline
\end{tabular}

Table 4: Inhibition zone diameter and MIC of volatile oil from Yongzhou Cinnamomum jensenianum

\begin{tabular}{lccccc}
\hline $\begin{array}{l}\text { Volume of } \\
\text { volatile oil } \\
(\boldsymbol{\mu L})\end{array}$ & $\begin{array}{c}\text { Escherichia } \\
\text { coli }\end{array}$ & $\begin{array}{l}\text { Bacillus } \\
\text { subtilis }\end{array}$ & $\begin{array}{c}\text { Staphylococcus } \\
\text { aureus }\end{array}$ & $\begin{array}{c}\text { Penicillium } \\
\text { Aspergillus } \\
\text { niger }\end{array}$ \\
\hline 5 & $12 \pm 0.23 \mathrm{a}$ & $15 \pm 0.27 \mathrm{a}$ & $18 \pm 0.34 \mathrm{a}$ & $24 \pm 0.31 \mathrm{a}$ & $36 \pm 0.32 \mathrm{a}$ \\
10 & $21 \pm 0.3 \mathrm{~b}$ & $29 \pm 0.22 \mathrm{~b}$ & $32 \pm 0.23 \mathrm{~b}$ & $35 \pm 0.28 \mathrm{~b}$ & $46 \pm 0.25 \mathrm{~b}$ \\
15 & $34 \pm 0.2 \mathrm{c}$ & $41 \pm 0.31 \mathrm{c}$ & $47 \pm 0.39 \mathrm{c}$ & $54 \pm 0.33 \mathrm{c}$ & - \\
20 & $56 \pm 0.3 \mathrm{~d}$ & $69 \pm 0.28 \mathrm{~d}$ & - & - & - \\
25 & - & - & - & - \\
\hline
\end{tabular}

"-" indicates no cell growth; each value is mean of 3 replicates \pm SD. Different letters depict significant differences at $p=0.05$

The minimum inhibitory concentration (MIC) of volatile oil was determined for each strain tested. The MIC value for Aspergillus niger was $10 \mathrm{uL}$; while the MIC for Penicillium and Staphylococcus aureus was $15 \mathrm{uL}$. For Escherichia coli and Bacillus subtilis, the MIC was $20 \mathrm{uL}$.

\section{$D P P H \cdot$ scavenging potential}

The DPPH. scavenging ability gradually increased with increase in volatile oil and BHT concentrations. When the concentration of volatile oil reached $0.09 \mathrm{mg} / \mathrm{mL}$, the volatile oil scavenged DPPH• more efficiently than BHT.

\section{DISCUSSION}

The essential oil produced by the secondary metabolism of Cinnamomum jensenianum Hand. Mazz is the main active component of the plant. Studies have demonstrated variabilities in characteristics, tissue structure, and material 
contents of the same plant resources grown in different regions [12-13]. This necessitated the study of Yongzhou Cinnamomum jensenianum Hand. Mazz. In this study, steam distillation method was used to extract volatile oil from the plant. Optimization of the extraction process showed that extraction duration of $5 \mathrm{~h}$, solidliquid ratio of $1: 12$, and soaking duration of $10 \mathrm{~h}$ resulted in volatile oil yield of $2.4 \pm 0.19 \%$. This yield is higher than what was obtained in previous studies.

The major component of the volatile oil was linalool, which accounted for $94.45 \%$. Linalool is widely used in flavors and fragrances, health care, synthetic vitamin $A$, synthetic anticancer drugs, deodorants, dental applications, insect repellents and insecticides. The annual demand of linalool for the formulation of various flavors worldwide is as high as 10,000 tons [13-15]. The present study has demonstrated that the volatile oil has good antibacterial and antifungal properties. The MICs were in the range $10-20$ $\mathrm{uL}$, which are better than MICs reported in previous studies. At a concentration $0.09 \mathrm{mg} /$ $\mathrm{mL}$, the DPPH scavenging capacity of the oil was stronger than that of BHT, and its antioxidant activity was also better. The antioxidant and antibacterial properties of the oil may be due to linalool, which is consistent with the report of Deepak [16-20]. Future studies will be focused on the composition, antibacterial activities and antioxidant activities of volatile oils of different origins, so as to provide theoretical support for research and comprehensive development of the volatile oils from this plant.

\section{CONCLUSION}

The content of volatile oil in Yongzhou Cinnamomum jensenianum Hand. Mazz is relatively high. The method of steam distillation is a simple and efficient method for obtaining volatile oil from this species. The volatile oil of Cinnamomum jensenianum Hand. Mazz has good antibacterial and antioxidant activities.

\section{DECLARATIONS}

\section{Acknowledgement}

We greatly acknowledge the financial supports from the Hunan Provincial Natural Science Fund (2018JJ3194).

\section{Conflict of interest}

No conflict of interest is associated with this work

\section{Contribution of authors}

We declare that this work was done by the author(s) named in this article and all liabilities pertaining to claims relating to the content of this article will be borne by the authors. All authors read and approved the manuscript for publication. He Fulin conceived and designed the study. Shao Jinhua, Zhang Yufei, Zhu Zhiyong, Chen Xiaoming, He Fulin collected and analysed the data, while Shao Jinhua wrote the manuscript.

\section{REFERENCES}

1. Wang Y, Qu F, Zhu L. Study on Antibacterial Activity of Cinnamomum jensenianum Hand. Mazz. J New Chin Med 2007; (05): 105-106.

2. Wang $Y$, Fan J, Xu D. Study on the chemical Components of Volatile Oil in the Leaves of Cinnamomum jensenianum Hand-Mazz by GC-MS. Lishizhen Med \& Mater Med Res 2007; 2923-2924.

3. Ghimire BK, Yoo JH, Yu CY, Chung IM. GC-MS analysis of volatile compounds of Perilla frutescens Britton var. Japonica accessions: Morphological and seasonal variability.Asian Pac J Trop Med 2017; 10(7): 643-651

4. Turgumbayeva AA, Ustenova GO, Yeskalieva BK, Ramazanova BA, Rahimov KD, Aisa H, Juszkiewicz KT. Volatile oil composition of Carthamus Tinctorius $L$. flowers grown in Kazakhstan. Ann Agric Environ Med 2018; 25(1): 87-89.

5. Zhao J, Jiang L, Tang $X$, Peng L, Li X, Zhao G, Zhong $L$. Chemical Composition, Antimicrobial and Antioxidant Activities of the Flower Volatile Oils of Fagopyrum esculentum, Fagopyrum tataricum and Fagopyrum Cymosum. Molecules 2018; 23(1): 182.

6. Ouyang T, Huang Y, Yuan J, Yang Q, Yan H, Liu D, Liu S. Antibacteria and Antioxidant Activities of the Volatile Oil of Cymbopogon Citraes from Different Regions. Nat Prod Res Dev 2018; 30(01): 65-72.

7. Lu Y, Meng C, Zhang SJ, Wang RS, Li WZ. Determination of Volatile Oil Components of Toona sinensis from Different Origins by GC-MS. J Chin Med Mater 2016; 39(11): 2539-2543.

8. Wang LX, Qian J, Zhao LN, Zhao SH. Effects of volatile oil from ginger on the murine B16 melanoma cells and its mechanism. Food Funct 2018; 9(2): 1058-1069.

9. Limoncu ME, Balcıŏlu C, Oyur T, Zeybek G, Zeybek U. In vitro Investigation of the Pediculicidal Activities of the Volatile Oil Components of Some Medical Plants Raised in Turkey. Turkiye Parazitol Derg 2017; 41(4): 208-213.

10. Tang YX, Ma MX, Zhu N, Zeng J, Li QM, Yang AD, Zhao JN. Quantitative Analysis of Volatile Oil and Curcuminoids in Curcumae Longae Rhizoma from Different Areas. Chin J Exp Tradit Med Formulae 2016; 22(05): 30-35. 
11. Qi MM, Li ZW, Li C, Sui D, Yan XF, Wang Y, Lin JX. Analysis and Comparison of Volatile Oil from Aralia elata by GC-MS. J Chin Med Mater 2016; 39(07): 15671570.

12. Labib RM, Youssef FS, Ashour ML, Abdel-Daim MM, Ross SA. Chemical Composition of Pinus roxburghii Bark Volatile Oil and Validation of Its Anti-Inflammatory Activity Using Molecular Modelling and BleomycinInduced Inflammation in Albino Mice. Mol 2017; 22(9): 1384.

13. Magnard JL, Bony AR, Bettini F, Campanaro A, Blerot B, Baudino S, Jullien F. Linalool and linalool nerolidol synthases in roses, several genes for little scent. Plant Physiol Biochem 2018; 127: 74-87.

14. Chen SY, Zhao LH, Xu XJ. Natural linalool resources and its development and utilization. For Sci \& Technol Dev 2013; 27(2): 13-17

15. Burdon RCF, Junker RR, Scofield DG, Parachnowitsch AL. Bacteria colonising Penstemon digitalis show volatile and tissue-specific responses to a natural concentration range of the floral volatile linalool. Chemoecology 2018; 28(1): 11-19.

16. Deepak S, Gyula O, Syagadadu GS, Nandini S, Shekar $S$, Sheena S. Antisporulantactivity of leaf extracts of
Indian plants against Sclerospora graminicola causing downy mildew disease of pearl millet. Arch Phytopathol Pflanzenschutz 2005; 38(1): 31-39.

17. Martins FT, Doriguetto AC, De STC, De SKR, Dos SMH, Moreira ME, Barbosa LC. Composition, and antiinflammatory and antioxidant activities of the volatile oil from the fruit peel of Garcinia brasiliensis. Chem Biodivers 2008; 5(2): 251-258.

18. Zhang TC. Advances in Applied Biotechnology Proceedings of the 2nd International Conference on Applied Biotechnology (ICAB 2014)-Volume I. [cited 2018 Aug 2]. Available from: https://link.springer.com/book/10.1007\%2F978-3-66245657-6.

19. Zhi Z. Flavor Volatiles in Three Rice Cultivars with Low Levels of Digestible Protein during Cooking. [cited 2018 Aug 2]. Available from: https://www.redorbit.com/news/business/1572392/flavor _volatiles_in_three_rice_cultivars_with_low_levels_of/.

20. Sinaa AAA. Undispensed Prescriptions due to Drug Unavailability at a Teaching Hospital in Saudi Arabia. [cited 2018 Aug 2]. Available from http://www.ajol.info/index.php/ijhr/article/download/7042 $4 / 58772$. 